\title{
Plasma 25-hydroxyvitamin D3 is associated with decreased risk of postmenopausal breast cancer in whites: a nested case-control study in the multiethnic cohort study
}

\author{
Yeonju Kim¹, Adrian A Franke², Yurii B Shvetsov', Lynne R Wilkens', Robert V Cooney³, Galina Lurie', \\ Gertraud Maskarinec ${ }^{1}$, Brenda Y Hernandez ${ }^{1}$, Loïc Le Marchand ${ }^{1}$, Brian E Henderson ${ }^{4}$, Laurence N Kolonel ${ }^{1}$ \\ and Marc T Goodman 1,5,6*
}

\begin{abstract}
Background: Higher sunlight exposure is correlated with lower incidence of breast cancer in ecological studies, but findings from prospective studies regarding the association of circulating levels of vitamin $D$ with the risk of breast cancer have been null. The objective of this study was to examine the relation between plasma levels of vitamin $D$ and the risk of postmenopausal breast cancer.

Methods: We conducted a nested case-control study within the Multiethnic Cohort Study of five race/ethnic groups (white, African-American, Native Hawaiian, Japanese, and Latino) from Hawaii and Los Angeles between 2001 and 2006. Pre-diagnostic plasma levels of 25-hydroxyvitamin D2 [25(OH) $\left.\mathrm{D}_{2}\right]$, 25-hydroxyvitamin D3 [25(OH) $\left.\mathrm{D}_{3}\right]$ and $25(\mathrm{OH}) \mathrm{D}$ (sum of $25(\mathrm{OH}) \mathrm{D}_{2}$ and $25(\mathrm{OH}) \mathrm{D}_{3}$ ) were examined among 707 postmenopausal breast cancer cases and matched controls.
\end{abstract}

Results: Using conditional logistic regression models, $20 \mathrm{ng} / \mathrm{mL}$ increases of plasma $25(\mathrm{OH}) \mathrm{D}_{3}$ (odds ratio (OR) 0.28; $95 \%$ confidence interval $(\mathrm{Cl})$ 0.14-0.56) and 25(OH)D (OR 0.43; 95\% Cl 0.23-0.80) were inversely associated with breast cancer risk among white women, but not among women in other race/ethnic groups. Using twosegmented, piecewise-linear logistic regression models, the change-points of the ORs, either for $25(\mathrm{OH}) \mathrm{D}_{3}$ or for 25 $(\mathrm{OH}) \mathrm{D}$, were detected as $20 \mathrm{ng} / \mathrm{mL}$ among whites.

Conclusions: Circulating $25(\mathrm{OH}) \mathrm{D}_{3}$ and $25(\mathrm{OH}) \mathrm{D}$ were associated with a reduced risk of postmenopausal breast cancer among whites, but not in other ethnic groups, who reside in low latitude regions.

Keywords: Breast cancer, 25-Hydroxyvitamin D3, 25-Hydroxyvitamin D2, Ethnic groups, Nested case-control study

\section{Background}

Ecological studies reporting a correlation between lower solar ultraviolet-B exposure and higher breast cancer incidence and/or mortality [1-3] contributed to the hypothesis that vitamin $\mathrm{D}$ may reduce breast cancer risk [4]. Results from retrospective case-control studies are

\footnotetext{
* Correspondence: marc.goodman@cshs.org

'Cancer Epidemiology Program, University of Hawaii Cancer Center, 701 Ilalo Street, Honolulu, HI 96813, USA

${ }^{5}$ Cancer Prevention and Control, Samuel Oschin Comprehensive Cancer Institute, Cedars-Sinai Medical Center, Los Angeles, CA 90048, USA Full list of author information is available at the end of the article
}

also suggestive of an inverse association of vitamin $\mathrm{D}$ intake [5] and circulating 25-hydroxyvitamin D (25(OH)D) [6-8] with the risk of breast cancer. However, results from cohort studies [9-16] and intervention trials $[17,18]$ of the association of circulating vitamin D with breast cancer incidence have been generally null $[7,8]$.

Epidemiological studies of the association of vitamin D with disease are complicated because circulating vitamin D levels are determined by a variety of factors, including ultraviolet radiation exposure, skin sensitivity to sun exposure, and diet [19-22]. Most investigations examining vitamin $\mathrm{D}$ and breast cancer risk have been conducted 
in whites, however; and circulating levels of $25(\mathrm{OH}) \mathrm{D}$, the most reliable indicator of vitamin D status, are known to differ substantially between race/ethnic groups with varying diets and ability to synthesize vitamin $\mathrm{D}$ in the skin $[19,21,23]$.

Among several forms of vitamin D, the two major forms are vitamin D3 (cholecalciferol) and vitamin D2 (ergocalciferol). Vitamin D3 is synthesized mostly from the irradiation of 7-hydrocholesterol on the skin and only a few foods naturally contain vitamin D3. In contrast, vitamin D2, at lower circulating levels than vitamin D3, is obtained from intake of foods, fortified products, and supplements. Since skin color is a determinant of synthesis to vitamin D3, it is important to examine the potential modifying influence of race/ethnicity on the relation of circulating vitamin D to disease risk. Specifically, it is unknown whether 25-hydroxyvitamin D2 $\left(25(\mathrm{OH}) \mathrm{D}_{2}\right)$ interacts with race/ ethnicity on the association of vitamin $\mathrm{D}$ with breast cancer risk.

It is plausible that the association of plasma 25-hydroxyvitamin $\mathrm{D} 325(\mathrm{OH}) \mathrm{D}_{3}$ and $25(\mathrm{OH}) \mathrm{D}$ with breast cancer risk is non-linear, and a minimum threshold is needed for vitamin $\mathrm{D}$ to exert a protective effect [5]. In this regard, the lower cutoff values that classify vitamin D levels as inadequate or deficient, recently suggested by the Institute of Medicine [24,25] and the Endocrine Society [26], were determined based on previous studies of skeletal health, the results of which may not be directly relevant to breast cancer risk.

We conducted a nested case-control study within the Multiethnic Cohort (MEC) in Hawaii and Los Angeles to test the hypothesis that pre-diagnostic plasma levels of $25(\mathrm{OH}) \mathrm{D}_{2}$ and $25(\mathrm{OH}) \mathrm{D}_{3}$ are associated with the risk of postmenopausal breast cancer, and that this association varies by race/ethnic group in populations with relatively high year-round levels of sunlight.

\section{Methods}

The MEC is a prospective study of more than 215,000 adults from five race/ethnic groups (white, AfricanAmerican, Native Hawaiian, Japanese, Latino) in Hawaii and Los Angeles that was established between 1993 and 1996 to examine the association of lifestyle and genes with chronic disease risk [27]. A biospecimen repository was developed within the MEC between 2001 and 2006 including 36,458 postmenopausal women, ages 45-75 years, who agreed to provide blood specimens and a short interview. The MEC was approved by the Institutional Review Boards of the University of Hawaii and the University of Southern California.

Incident invasive breast cancer cases were identified by linkage to the Surveillance, Epidemiology, and End Results Program registries in the states of Hawaii and California through October, 2010, including 729 eligible postmenopausal women with a diagnosis of invasive breast cancer.
Controls who were alive and free of breast cancer were randomly selected from the pool of postmenopausal women in the biospecimen repository and matched 1:1 to each case within strata of geographic location (Hawaii or California), race/ethnicity, birth year $( \pm 1 \mathrm{y})$, date of blood draw $( \pm 6 \mathrm{mo})$, time of blood draw $( \pm 2 \mathrm{~h})$, hours fasting prior to blood draw $(0-<6,6-<8,8-<10$, and $\geq 10 \mathrm{~h})$, and hormone replacement therapy use (HRT; as current versus not current). Matched pairs that included a case or control with $25(\mathrm{OH}) \mathrm{D}_{2}$ or $25(\mathrm{OH}) \mathrm{D}_{3}$ measurements below the limits of detection (10 cases and 10 controls), or outliers (higher levels than three standard deviation (3 cases for 25 $(\mathrm{OH}) \mathrm{D}_{2}$, none for $\left.\left.25(\mathrm{OH}) \mathrm{D}_{3}\right)\right)$, were excluded. After exclusion, 707 matched sets remained for statistical analysis.

Plasma levels of $25(\mathrm{OH}) \mathrm{D}_{2}$ and $25(\mathrm{OH}) \mathrm{D}_{3}$ were analyzed by isotope dilution liquid chromatography orbitrap mass spectrometry (Laboratory of AAF, ThermoFisher Scientific, Waltham, MA). The assay was validated by the Vitamin D External Quality Assessment Scheme (DEQAS) and National Institute of Standards and Technology (NIST) quality assurance programs. Intra- and inter-assay variability coefficients of variations of $25(\mathrm{OH}) \mathrm{D}$ which was the sum of $25(\mathrm{OH}) \mathrm{D}_{2}$ and $25(\mathrm{OH}) \mathrm{D}_{3}$, were $6.8 \%$ and $7.4 \%$, based on the analysis of 47 duplicate and 23 triplicate samples.

Conditional logistic regression with matched sets as strata was used to compute odds ratios (ORs) and 95\% confidence intervals (CIs). Levels of $25(\mathrm{OH}) \mathrm{D}_{2}$ were coded as a binary variable $(0,>0 \mathrm{ng} / \mathrm{mL})$ because the detection level of 25 $(\mathrm{OH}) \mathrm{D}_{2}$ was low. For $25(\mathrm{OH}) \mathrm{D}_{3}$ and $25(\mathrm{OH}) \mathrm{D}$, we used continuous variables $(10 \mathrm{ng} / \mathrm{mL}$ and $20 \mathrm{ng} / \mathrm{mL})$ to facilitate comparison with our results and results from the latest meta-analyses $[7,8]$. For $25(\mathrm{OH}) \mathrm{D}$, binary variables using several cutoffs $(16,20$, and $30 \mathrm{ng} / \mathrm{mL})$ were also used based on the recent definition of vitamin $\mathrm{D}$ deficiency or insufficiency $[25,26]$. Heterogeneity of effect across race/ethnic groups was tested by the Wald test of the cross-product terms for vitamin D and ethnic group. All statistical models were adjusted for potential confounders, including body mass index $\left(<25.0,25.0-29.9, \geq 30.0 \mathrm{~kg} / \mathrm{m}^{2}\right)$, number of live births (never, 1, 2-3, $\geq 4$, missing), family history of breast cancer (yes, no, missing), use of multivitamin and calcium supplements (yes: taken at least once a week in the last year preceding blood draw; no; missing), season (October to March, April to September), sunburn history (yes, no, missing), and engagement in strenuous sports (never, $\leq 1 \mathrm{~h} /$ week, >1 h/week, missing). The study participants were queried about the frequency and duration of intake of calcium supplements regardless of alone or in combination with vitamin D.

Sensitivity analyses for $25(\mathrm{OH}) \mathrm{D}_{3}$ and $25(\mathrm{OH}) \mathrm{D}$ were performed among whites by excluding women (by casecontrol pair) within 6 months, one, two, three, and four years from the date of blood draw. To find the change- 
point in ORs to identify a threshold effect of $25(\mathrm{OH}) \mathrm{D}_{3}$ and $25(\mathrm{OH}) \mathrm{D}$ on breast cancer risk, we implemented a two-segmented piecewise-linear logistic regression for each race/ethnic group [28].

\section{Results}

The mean age of the study subjects was 67.8 years (Table 1) and the mean time between the date of blood draw and the date of breast cancer diagnosis was 3.1 years. Compared to controls, in all five race/ethnic groups, cases were likely to be overweight and obese or to have a family history of breast cancer. Dietary and supplementary intake for energy, vitamin D and calcium was not different between cases and controls in every race/ethnic group. Among controls, the mean plasma $25(\mathrm{OH}) \mathrm{D}_{2}$ levels were the highest among African-Americans and Japanese, and the lowest among whites. In contrast, mean plasma $25(\mathrm{OH}) \mathrm{D}_{3}$ and $25(\mathrm{OH}) \mathrm{D}$ levels were the highest among whites and the lowest among African-Americans.

Plasma concentrations of $25(\mathrm{OH}) \mathrm{D}_{2}$ were inversely associated with breast cancer risk among African-American women (>0 ng/mL vs $0 \mathrm{ng} / \mathrm{mL}$ : OR 0.29 ; $95 \%$ CI $0.12-$ $0.70)$, but not among women in other race/ethnic groups (Table 2). A unit increase of $20 \mathrm{ng} / \mathrm{mL}$ in plasma concentrations of $25(\mathrm{OH}) \mathrm{D}_{3}(\mathrm{OR} 0.28 ; 95 \%$ CI 0.14-0.56) was inversely associated with postmenopausal breast cancer risk among white women, but not among women in other race/ethnic groups (test for heterogeneity, $\mathrm{P}=0.007$ ). Among whites, plasma levels of 25(OH)D considered deficient $(<20 \mathrm{ng} / \mathrm{ml})$ led to a 7.5 times greater risk of breast cancer (95\% CI 1.41-39.8) compared to women with circulating levels of $25(\mathrm{OH}) \mathrm{D}$ at $20 \mathrm{ng} / \mathrm{mL}$ or more. For women other than non-Hispanic whites, the association of plasma $25(\mathrm{OH}) \mathrm{D}$ levels with breast cancer risk was not statistically significant.

Among whites, results from a two-segmented piecewiselinear logistic regression yielded a threshold at $19.4 \mathrm{ng} / \mathrm{mL}$ for $25(\mathrm{OH}) \mathrm{D}_{3}$ (for unit increase in $25(\mathrm{OH}) \mathrm{D}_{3}$, OR 1.11, 95\% CI: 0.98-1.25 below the change-point; OR 0.96, 95\% CI: 0.92-0.99 above the change-point; test for heterogeneity $\mathrm{P}=0.007$ ) and at $19.5 \mathrm{ng} / \mathrm{mL}$ for $25(\mathrm{OH}) \mathrm{D}$ (for unit increase in 25(OH)D, OR 1.20, 95\% CI: 0.97-1.48) below the change-point; OR $0.98,95 \%$ CI: $0.95-1.01$ above the change-point; test for heterogeneity $\mathrm{P}=0.046$ ) (data not shown). Change-points, either for $25(\mathrm{OH}) \mathrm{D}_{3}$ or for 25 $(\mathrm{OH}) \mathrm{D}$, were not detected among African-American, Native Hawaiian, Japanese, or Latino women.

In sensitivity analyses, no heterogeneity by length of follow-up time after blood draw was detected in the risk estimates by a unit increase of $20 \mathrm{ng} / \mathrm{mL}$ of plasma 25 $(\mathrm{OH}) \mathrm{D}_{3}$ or of plasma $25(\mathrm{OH}) \mathrm{D}$ concentrations for postmenopausal breast cancer among whites (test for heterogeneity $\mathrm{P}=0.939$ for $25(\mathrm{OH}) \mathrm{D}_{3} ; \mathrm{P}=0.265$ for $\left.25(\mathrm{OH}) \mathrm{D}\right)$ (data not shown).

\section{Discussion}

Results from this study add to the growing debate regarding the potential beneficial effects of vitamin D against breast cancer and other malignancies [29,30]. Higher circulating vitamin D3 and vitamin D levels were associated with a lower risk of postmenopausal breast cancer among white women whose circulating $25(\mathrm{OH}) \mathrm{D}_{3}$ and $25(\mathrm{OH}) \mathrm{D}$ levels exceeded those of women in other race/ethnic groups.

Vitamin D3, which is the major form of vitamin D, is obtained from the diet or through synthesis in the skin from the action of ultraviolet radiation [31]. The inverse association found in this analysis among white women may be explained by the relatively high levels of circulating vitamin D3 achievable among whites living in Los Angeles and Hawaii where ambient levels of ultraviolet radiation are sufficiently elevated throughout the year for adequate cutaneous vitamin $\mathrm{D}$ production. White women in our study had higher plasma 25(OH)D levels (means of $34.9 \mathrm{ng} / \mathrm{mL}$ in cases and of 37.4 in controls) compared to white women in previous nested case-control studies, with ranges from 20.0 to $31.5 \mathrm{ng} / \mathrm{mL}$ among cases and 20.4 to $33.1 \mathrm{ng} / \mathrm{mL}$ among controls $[9-15,17,18]$. This observation is consistent with findings from prospective studies of dietary vitamin D, sun exposure, and breast cancer risk in France [32] and in the United States [33] which showed a lower risk of breast cancer among women who were high dietary vitamin D consumers living in southern regions, but not in northern regions, of these countries.

A meta-analysis of studies measuring plasma $25(\mathrm{OH}) \mathrm{D}$ levels and breast cancer risk reported a lower risk of breast cancer associated with a $10 \mathrm{ng} / \mathrm{mL}$ increase [7] or $20 \mathrm{ng} / \mathrm{mL}$ increase [8] in pooled estimates; however, when the pooled analysis was restricted to prospective studies, this association was null. Our data support the hypothesis that a minimum threshold level of $25(\mathrm{OH}) \mathrm{D}$ exceeding $20 \mathrm{ng} / \mathrm{ml}$ is necessary for an inverse association with postmenopausal breast cancer risk to be measurable, although the modest number of subjects below this threshold was a concern. A threshold effect rather than a dose-dependent effect of vitamin $\mathrm{D}$ with breast cancer risk was recently supported by a re-analysis of data from the Women's Health Initiative [34]: the beneficial effect of vitamin $\mathrm{D}$ on reducing breast cancer was examined among women who were not using calcium or vitamin D supplements at baseline, while higher doses of vitamin D did not further decrease breast cancer incidence among women who were using supplements at baseline.

To our knowledge, this is the first case-control study nested in a prospective cohort that examined the association between circulating vitamin D3 and vitamin D (sum of vitamin D2 vitamin D3) concentrations and breast cancer risk in a multiethnic population. Our finding that white women had the highest circulating vitamin D3 and/ 
Table 1 Basic characteristics of postmenopausal breast cancer cases and controls by race/ethnicity

\begin{tabular}{|c|c|c|c|c|c|c|c|c|c|c|c|c|c|c|c|c|c|c|c|c|}
\hline & \multicolumn{4}{|c|}{$\begin{array}{c}\text { White } \\
(n=294)\end{array}$} & \multicolumn{4}{|c|}{$\begin{array}{l}\text { African-American } \\
\qquad(\mathrm{n}=212)\end{array}$} & \multicolumn{4}{|c|}{$\begin{array}{l}\text { Native Hawaiian } \\
\qquad(n=136)\end{array}$} & \multicolumn{4}{|c|}{$\begin{array}{l}\text { Japanese } \\
(n=508)\end{array}$} & \multicolumn{4}{|c|}{$\begin{array}{l}\text { Latino } \\
(n=264)\end{array}$} \\
\hline & \multicolumn{2}{|c|}{ Cases } & \multicolumn{2}{|c|}{ Controls } & \multicolumn{2}{|c|}{ Cases } & \multicolumn{2}{|c|}{ Controls } & \multicolumn{2}{|c|}{ Cases } & \multicolumn{2}{|c|}{ Controls } & \multicolumn{2}{|c|}{ Cases } & \multicolumn{2}{|c|}{ Controls } & \multicolumn{2}{|c|}{ Cases } & \multicolumn{2}{|c|}{ Controls } \\
\hline & No. & $\%$ & No. & $\overline{\%}$ & No. & $\overline{\%}$ & No. & $\overline{\%}$ & No. & $\overline{\%}$ & No. & $\overline{\%}$ & No. & $\%$ & No. & $\overline{\%}$ & No. & $\overline{\%}$ & No. & $\%$ \\
\hline \multicolumn{21}{|l|}{ Area } \\
\hline Hawaii & 137 & 93.2 & 137 & 93.2 & & & & & 68 & 100.0 & 68 & 100.0 & 215 & 84.6 & 215 & 84.6 & & & & \\
\hline LA & 10 & 6.8 & 10 & 6.8 & 106 & 100.0 & 106 & 100.0 & & & & & 39 & 15.4 & 39 & 15.4 & 132 & 100.0 & 132 & 100.0 \\
\hline \multicolumn{21}{|l|}{ Season } \\
\hline Oct-Mar & 65 & 44.2 & 68 & 46.3 & 54 & 50.9 & 57 & 53.8 & 38 & 55.9 & 36 & 52.9 & 98 & 38.6 & 119 & 46.8 & 70 & 53.0 & 57 & 43.2 \\
\hline Apr-Sep & 82 & 55.8 & 79 & 53.7 & 52 & 49.1 & 49 & 46.2 & 30 & 44.1 & 32 & 47.1 & 156 & 61.4 & 135 & 53.2 & 62 & 47.0 & 75 & 56.8 \\
\hline Sunburn history & 103 & 70.1 & 98 & 67.1 & 17 & 16.2 & 9 & 9.0 & 21 & 31.3 & 23 & 33.8 & 48 & 19.0 & 54 & 21.4 & 40 & 32.3 & 28 & 22.8 \\
\hline Family history of breast cancer & 22 & 15.0 & 13 & 8.8 & 21 & 19.8 & 22 & 20.8 & 12 & 17.6 & 10 & 14.7 & 38 & 15.0 & 28 & 11.0 & 15 & 11.4 & 8 & 6.1 \\
\hline Use of multivitamins & 82 & 56.6 & 73 & 50.3 & 59 & 56.7 & 56 & 55.4 & 36 & 52.9 & 33 & 49.3 & 135 & 53.4 & 126 & 50.0 & 63 & 48.8 & 69 & 52.7 \\
\hline \multirow[t]{2}{*}{ Use of calcium supplements } & 68 & 47.9 & 62 & 43.4 & 29 & 29.9 & 38 & 36.9 & 18 & 26.5 & 28 & 43.1 & 114 & 45.8 & 139 & 55.6 & 52 & 42.3 & 48 & 38.4 \\
\hline & Mean & SD & Mean & SD & Mean & SD & Mean & SD & Mean & SD & Mean & SD & Mean & SD & Mean & SD & Mean & SD & Mean & SD \\
\hline Age & 68.5 & 7.9 & 68.4 & 7.7 & 69.1 & 7.6 & 69.2 & 7.5 & 65.7 & 6.8 & 65.8 & 6.8 & 67.8 & 7.7 & 67.8 & 7.7 & 67.3 & 6.7 & 67.3 & 6.8 \\
\hline Body mass index $\left(\mathrm{kg} / \mathrm{m}^{2}\right)$ & 25.0 & 4.5 & 24.5 & 5.4 & 28.0 & 5.0 & 28.4 & 5.7 & 27.8 & 5.5 & 28.1 & 6.2 & 24.2 & 4.2 & 23.3 & 3.8 & 28.2 & 5.7 & 27.3 & 5.6 \\
\hline Live births & 2.3 & 1.6 & 2.7 & 1.6 & 2.9 & 1.8 & 2.9 & 2.0 & 3.5 & 2.0 & 3.5 & 1.7 & 2.2 & 1.4 & 2.3 & 1.4 & 3.5 & 2.0 & 4.1 & 2.0 \\
\hline Sports activity (hour/week) & 0.2 & 0.3 & 0.2 & 0.5 & 0.1 & 0.3 & 0.1 & 0.2 & 0.2 & 0.7 & 0.2 & 0.4 & 0.1 & 0.3 & 0.1 & 0.2 & 0.1 & 0.4 & 0.1 & 0.4 \\
\hline Energy intake, Kcal/day & 1,799 & 649 & 1,785 & 714 & 1,848 & 1,043 & 1,834 & 1,010 & 2,295 & 1,191 & 2,031 & 1,092 & 1,814 & 670 & 1,900 & 658 & 2,189 & 1,199 & 2,222 & 1,369 \\
\hline Vitamin D, IU/1000 Kcal/day & 78 & 44 & 81 & 52 & 74 & 52 & 70 & 52 & 74 & 47 & 81 & 56 & 62 & 38 & 61 & 36 & 72 & 44 & 70 & 58 \\
\hline Calcium, mg/1000 Kcal/day & 438 & 136 & 436 & 144 & 400 & 146 & 384 & 145 & 361 & 140 & 371 & 170 & 336 & 108 & 331 & 109 & 467 & 142 & 463 & 164 \\
\hline Phosphorus, mg/1000 Kcal/day & 650 & 123 & 658 & 122 & 651 & 137 & 631 & 129 & 578 & 124 & 604 & 139 & 580 & 101 & 568 & 104 & 687 & 127 & 699 & 144 \\
\hline Plasma $25(\mathrm{OH}) \mathrm{D}_{2}, \mathrm{ng} / \mathrm{mL}^{\mathrm{a}}$ & 3.5 & 5.4 & 2.6 & 4.7 & 2.2 & 5.0 & 3.3 & 5.5 & 1.7 & 3.8 & 2.8 & 5.3 & 4.3 & 5.7 & 3.3 & 4.9 & 2.5 & 4.5 & 3.0 & 5.4 \\
\hline Plasma $25(\mathrm{OH}) \mathrm{D}_{3}, \mathrm{ng} / \mathrm{mL}^{\mathrm{a}}$ & 31.4 & 10.1 & 34.8 & 10.1 & 23.5 & 12.3 & 23.1 & 9.6 & 30.9 & 9.5 & 30.6 & 11.6 & 28.5 & 9.4 & 29.3 & 10.5 & 25.2 & 8.1 & 24.1 & 8.5 \\
\hline Plasma 25(OH)D, ng/mL ${ }^{a}$ & 34.9 & 10.2 & 37.4 & 9.7 & 25.7 & 12.1 & 26.4 & 11.3 & 32.6 & 8.7 & 33.4 & 12.2 & 32.7 & 9.3 & 32.6 & 10.2 & 27.7 & 9.4 & 27.1 & 9.4 \\
\hline
\end{tabular}

Abbreviation: $\mathrm{SD}$ standard deviation, $25(\mathrm{OH}) \mathrm{D}_{2} 25$-hydroxyvitamin $\mathrm{D} 2,25(\mathrm{OH}) \mathrm{D}_{3}$ 25-hydroxyvitamin $\mathrm{D} 3,25(\mathrm{OH}) \mathrm{D}$ sum of $25(\mathrm{OH}) \mathrm{D}_{2}$ and $25(\mathrm{OH}) \mathrm{D}_{3}$.

${ }^{a}$ Multiply 2.5 to convert the values to $\mathrm{nmol} / \mathrm{L}$. 
Table 2 Odds ratio (OR) and 95\% confidence intervals (Cl) for breast cancer by categories in circulating $25(\mathrm{OH}) \mathrm{D}_{2}, \mathbf{2 5}(\mathrm{OH}) \mathrm{D}_{3}$, and $25(\mathrm{OH}) \mathrm{D}$ levels by race/ethnicity ${ }^{\mathrm{a}}$

\begin{tabular}{|c|c|c|c|c|c|c|c|c|c|c|c|c|c|c|c|c|c|c|c|c|c|c|}
\hline \multirow[b]{2}{*}{$\begin{array}{l}\text { Variables } \\
\text { and categories }\end{array}$} & \multicolumn{4}{|c|}{$\begin{array}{c}\text { White } \\
(n=294)\end{array}$} & \multicolumn{4}{|c|}{$\begin{array}{l}\text { African-American } \\
\quad(n=212)\end{array}$} & \multicolumn{4}{|c|}{$\begin{array}{l}\text { Native Hawaiian } \\
\qquad(n=136)\end{array}$} & \multicolumn{4}{|c|}{$\begin{array}{c}\text { Japanese } \\
(n=508)\end{array}$} & \multicolumn{4}{|c|}{$\begin{array}{l}\text { Latino } \\
(n=264)\end{array}$} & \multicolumn{2}{|c|}{$\begin{array}{c}\text { Test for } \\
\text { heterogeneity }\end{array}$} \\
\hline & $\begin{array}{l}\text { No. } \\
\text { cases/ } \\
\text { controls }\end{array}$ & OR & \multicolumn{2}{|c|}{$95 \% \mathrm{Cl}$} & $\begin{array}{c}\text { No. } \\
\text { cases/ } \\
\text { controls }\end{array}$ & OR & \multicolumn{2}{|c|}{$95 \% \mathrm{Cl}$} & $\begin{array}{c}\text { No. } \\
\text { cases/ } \\
\text { controls }\end{array}$ & OR & \multicolumn{2}{|c|}{$95 \% \mathrm{Cl}$} & $\begin{array}{c}\text { No. } \\
\text { cases/ } \\
\text { controls }\end{array}$ & OR & \multicolumn{2}{|c|}{$95 \% \mathrm{Cl}$} & $\begin{array}{l}\text { No. } \\
\text { cases/ } \\
\text { controls }\end{array}$ & OR & \multicolumn{2}{|c|}{$95 \% \mathrm{Cl}$} & Overall & $\begin{array}{c}\text { Whites } \\
\text { vs. others }\end{array}$ \\
\hline \multicolumn{23}{|l|}{$25(\mathrm{OH}) \mathrm{D}_{2}$} \\
\hline $0 \mathrm{ng} / \mathrm{mL}$ & $80 / 90$ & 1.00 & & & $85 / 66$ & 1.00 & & & $49 / 43$ & 1.00 & & & $124 / 139$ & 1.00 & & & $84 / 83$ & 1.00 & & & & \\
\hline$>0 \mathrm{ng} / \mathrm{mL}$ & $67 / 57$ & 1.29 & 0.75 & 2.23 & $21 / 40$ & 0.29 & 0.12 & 0.70 & $19 / 25$ & 0.46 & 0.16 & 1.34 & $130 / 115$ & 1.32 & 0.90 & 1.93 & $48 / 49$ & 0.85 & 0.46 & 1.56 & $P=0.817$ & $P=0.124$ \\
\hline \multicolumn{23}{|l|}{$25(\mathrm{OH}) \mathrm{D}_{3}$} \\
\hline 10 ng/mL increase & $147 / 147$ & 0.53 & 0.37 & 0.75 & $106 / 106$ & 1.27 & 0.91 & 1.76 & $118 / 118$ & 0.89 & 0.59 & 1.34 & $229 / 229$ & 0.92 & 0.75 & 1.12 & $232 / 232$ & 1.29 & 0.87 & 1.89 & $P=0.059$ & $P=0.007$ \\
\hline 20 ng/mL increase & $147 / 147$ & 0.28 & 0.14 & 0.56 & 106/106 & 1.61 & 0.83 & 3.11 & $118 / 118$ & 0.80 & 0.35 & 1.79 & $229 / 229$ & 0.84 & 0.57 & 1.24 & $232 / 232$ & 1.65 & 0.76 & 3.57 & & \\
\hline \multicolumn{23}{|l|}{$25(\mathrm{OH}) \mathrm{D}$} \\
\hline 10 ng/mL increase & $147 / 147$ & 0.66 & 0.48 & 0.90 & 106/106 & 1.08 & 0.79 & 1.47 & 118/118 & 0.79 & 0.52 & 1.20 & 229/229 & 1.04 & 0.84 & 1.28 & $232 / 232$ & 1.17 & 0.84 & 1.64 & $P=0.086$ & $P=0.051$ \\
\hline 20 ng/mL increase & $147 / 147$ & 0.43 & 0.23 & 0.80 & 106/106 & 1.16 & 0.63 & 2.16 & $118 / 118$ & 0.63 & 0.27 & 1.45 & $229 / 229$ & 1.08 & 0.71 & 1.65 & 232/232 & 1.38 & 0.71 & 2.69 & & \\
\hline \multicolumn{23}{|l|}{ Vitamin D deficiency } \\
\hline \multicolumn{23}{|l|}{ Cutoff at $16 \mathrm{ng} / \mathrm{mL}$} \\
\hline$\geq 16 \mathrm{ng} / \mathrm{mL}$ & $144 / 146$ & 1.00 & & & $79 / 85$ & 1.00 & & & $65 / 64$ & 1.00 & & & $246 / 245$ & 1.00 & & & $119 / 119$ & 1.00 & & & & \\
\hline$<16 \mathrm{ng} / \mathrm{mL}$ & $3 / 1$ & 4.98 & 0.40 & 62.1 & $27 / 21$ & 1.36 & 0.59 & 3.13 & $3 / 4$ & 1.44 & 0.18 & 11.5 & $8 / 9$ & 0.72 & 0.24 & 2.14 & $13 / 13$ & 1.01 & 0.31 & 3.29 & $P=0.395$ & $P=0.465$ \\
\hline \multicolumn{23}{|l|}{ Cutoff at $20 \mathrm{ng} / \mathrm{mL}$} \\
\hline$\geq 20 \mathrm{ng} / \mathrm{mL}$ & $136 / 145$ & 1.00 & & & $72 / 70$ & 1.00 & & & $64 / 61$ & 1.00 & & & $233 / 231$ & 1.00 & & & $105 / 102$ & 1.00 & & & & \\
\hline$<20 \mathrm{ng} / \mathrm{mL}$ & $11 / 2$ & 7.50 & 1.41 & 39.8 & $34 / 36$ & 0.74 & 0.36 & 1.53 & $4 / 7$ & 0.74 & 0.13 & 4.29 & $21 / 23$ & 0.96 & 0.47 & 1.97 & $27 / 30$ & 0.90 & 0.41 & 1.95 & $P=0.226$ & $P=0.023$ \\
\hline \multicolumn{23}{|l|}{ Cutoff at $30 \mathrm{ng} / \mathrm{mL}$} \\
\hline$\geq 30 \mathrm{ng} / \mathrm{mL}$ & $98 / 115$ & 1.00 & & & $29 / 39$ & 1.00 & & & $44 / 39$ & 1.00 & & & $152 / 144$ & 1.00 & & & $45 / 42$ & 1.00 & & & & \\
\hline$<30 \mathrm{ng} / \mathrm{mL}$ & $49 / 32$ & 2.56 & 1.27 & 5.14 & $77 / 67$ & 1.34 & 0.64 & 2.79 & $24 / 29$ & 0.64 & 0.28 & 1.49 & $102 / 110$ & 0.86 & 0.58 & 1.29 & $87 / 90$ & 0.76 & 0.40 & 1.46 & $P=0.025$ & $P=0.026$ \\
\hline
\end{tabular}

Abbreviation: $25(\mathrm{OH}) \mathrm{D}_{2}$ 25-hydroxyvitamin $\mathrm{D} 2,25(\mathrm{OH}) \mathrm{D}_{3} 25$-hydroxyvitamin $\mathrm{D} 3,25(\mathrm{OH}) \mathrm{D}$ sum of $25(\mathrm{OH}) \mathrm{D}_{2}$ and $25(\mathrm{OH}) \mathrm{D}_{3}$.

Note. Values are given in $\mathrm{ng} / \mathrm{mL}$. Multiply 2.5 to convert the values to $\mathrm{nmol} / \mathrm{L}$

${ }^{a}$ Modeled through conditional logistic regression after adjustment for season, sunburn history, body mass index, strenuous sports, number of live births, family history of breast cancer, use of multivitamin, and use of

calcium supplement

calcium supplement.
${ }^{b}$ Tests based on the Wald statistic for cross-product terms between ethnicity and plasma vitamin D level. 
or vitamin D concentrations is consistent with reports from previous cross-sectional studies [21,23,35-38]. One possible explanation for the unique association of vitamin $\mathrm{D}$ with breast cancer risk among white women is a potential modifying effect of this association by vitamin $D$ receptor polymorphisms (FokI, BgII) that vary substantially by ethnic group [39-43]. The vitamin $\mathrm{D}$ receptor binds the active form of $25(\mathrm{OH}) \mathrm{D}$ (i.e., 1,25 dihydroxyvitamin $\mathrm{D}$ $\left.\left(1,25(\mathrm{OH})_{2} \mathrm{D}\right)\right)$ in the nucleus of breast epithelial cells, thereby reducing cell proliferation, and increasing cell differentiation, autophagy and apoptosis [44]. However, it is also possible that light skin pigmentation combined with high sun exposure, rather than differences in vitamin D receptor polymorphisms among whites compared to other women, account for the reduction in breast cancer risk limited to this race/ethnic group $[37,45]$.

In contrast to the results for vitamin D3, we found that a modest reduction in the risk of breast cancer is associated with higher levels of plasma vitamin D2 among AfricanAmerican women. African-Americans had the lowest plasma $25(\mathrm{OH}) \mathrm{D}_{3}$ among the five race/ethnic groups studied. It is possible that the apparent ethnic-specific effect of circulating vitamin D2 on breast cancer risk among African-American women resulted from their relatively low levels of circulating vitamin D3 compared to other race/ethnic groups which may have masked a modest association of risk with vitamin D3. Vitamin D2 (ergocalciferol) is derived from irradiation of plants or yeast and is found in humans when ingested from food or supplements [46]. Recent literature suggests that the binding affinity of vitamin D2 and its metabolites to plasma vitamin D binding protein is weaker than that of vitamin D3 $[47,48]$, but little is known about the physiologic effects or ethnic-specific potency of vitamin D2. Plasma $25(\mathrm{OH}) \mathrm{D}_{2}$ levels in our study participants were generally above the assay detection limit, although it is still possible that the association found among white women in our study resulted from chance.

Strengths of this study include its multiethnic composition, the use of pre-diagnosed biologic samples, and a relatively large number of carefully matched cases and controls. High circulating levels of vitamin D in both cases and controls may have attenuated the risk estimates, but study power remained adequate. A further strength of our analysis was the ability to adjust for body mass index, physical activity, as well as calcium and vitamin supplements, factors which are correlated with circulating 25(OH)D levels [49]. Because this information was gathered using a mail survey form, recall may have been imperfect. However, all women included in this analysis were healthy at the time of interview, so any biased responses would be non-differential and likely to attenuate risk estimates toward the null. The number of cases and controls in each ethnic group was not sufficient to stratify the analyses by geographical area and/or by season which is a possible limitation.

\section{Conclusion}

In conclusion, plasma vitamin D was inversely associated with postmenopausal breast cancer risk among white women who reside in latitudes where levels of ultraviolet radiation are comparatively high. It is likely that a minimum threshold of vitamin D exposure from both sun and diet is required to achieve a reduction in breast cancer risk among postmenopausal white women.

\section{Competing interest}

The authors declare that they have no conflict of interest.

\section{Authors' contributions}

YK participated in the design of the study, performed the statistical analysis, and drafted the manuscript. AAF made substantial contributions to conception and design, acquisition of data, and carried out the laboratory analysis. YBS performed the statistical analysis, contributed to interpretation of data, and helped draft the manuscript. GL made contributions to interpretation of the data. LRW, RVC, GM, BYH, LLM, BEH, LNK, and MTG made substantial contributions to conception and design, acquisition of data, and interpretation of data. MTG also helped draft the manuscript. All authors have been involved in revising the manuscript critically for important intellectual content, and have given final approval of the version to be published.

\section{Acknowledgments}

We thank Laurie Custer for the technical assistance in measuring vitamin D metabolites by LCMS. This work was supported by the National Institute of Health through grants R37- CA54281, P30-CA71789 and S10-RR020890.

\section{Author details}

${ }^{1}$ Cancer Epidemiology Program, University of Hawaii Cancer Center, 701 Ilalo Street, Honolulu, HI 96813, USA. ${ }^{2}$ Cancer Biology Program, University of Hawaii Cancer Center, 1236 Lauhala Street, Honolulu, HI 96813, USA ${ }^{3}$ Department of Public Health Sciences \& Epidemiology, University of Hawaii, 1960 East West Road, Biomed D104K, Honolulu, HI 96822, USA. ${ }^{4}$ Department of Preventive Medicine, Keck School of Medicine, University of Southern California, 1450 Biggy Street, NRT 1517 J, Los Angeles, CA 90033, USA. ${ }^{5}$ Cancer Prevention and Control, Samuel Oschin Comprehensive Cancer Institute, Cedars-Sinai Medical Center, Los Angeles, CA 90048, USA.

${ }^{6}$ Community and Population Health Research Institute, Department of Biomedical Sciences, Cedars-Sinai Medical Center, 8700 Beverly Blvd, Room 1S37, Los Angeles, CA, 90048, USA.

Received: 3 September 2013 Accepted: 14 January 2014 Published: 17 January 2014

\section{References}

1. Boscoe FP, Schymura MJ: Solar ultraviolet-B exposure and cancer incidence and mortality in the United States, 1993-2002. BMC Cancer 2006, 6:264

2. Gorham ED, Garland FC, Garland CF: Sunlight and breast cancer incidence in the USSR. Int J Epidemiol 1990, 19(4):820-824.

3. Grant WB: An estimate of premature cancer mortality in the U.S. due to inadequate doses of solar ultraviolet-B radiation. Cancer 2002, 94(6):1867-1875.

4. IARC: Vitamin D and cancer. IARC Working group reports vol.5, Volume 5. Lyon: International Agency for research on Cancer; 2008.

5. Gissel T, Rejnmark L, Mosekilde L, Vestergaard P: Intake of vitamin D and risk of breast cancer-a meta-analysis. J Steroid Biochem Mol Biol 2008, 111(3-5):195-199.

6. Garland CF, Gorham ED, Mohr SB, Grant WB, Giovannucci EL, Lipkin M, Newmark H, Holick MF, Garland FC: Vitamin D and prevention of breast cancer: pooled analysis. J Steroid Biochem Mol Biol 2007, 103(3-5):708-711.

7. Gandini S, Boniol M, Haukka J, Byrnes G, Cox B, Sneyd MJ, Mullie P, Autier P: Meta-analysis of observational studies of serum 25-hydroxyvitamin D levels and colorectal, breast and prostate cancer and colorectal adenoma. Int J Cancer 2011, 128(6):1414-1424

8. Yin L, Grandi N, Raum E, Haug U, Arndt V, Brenner H: Meta-analysis: serum vitamin D and breast cancer risk. Eur J Cancer 2010, 46(12):2196-2205. 
9. Almquist M, Bondeson AG, Bondeson L, Malm J, Manjer J: Serum levels of vitamin D, PTH and calcium and breast cancer risk-a prospective nested case-control study. Int J Cancer 2010, 127(9):2159-2168.

10. Bertone-Johnson ER, Chen WY, Holick MF, Hollis BW, Colditz GA, Willett WC, Hankinson SE: Plasma 25-Hydroxyvitamin D and 1,25-Dihydroxyvitamin D and risk of breast cancer. Cancer Epidemiol Bioiomarkers Prev 2005, 14(8):1991-1997.

11. Eliassen AH, Spiegelman D, Hollis BW, Horst RL, Willett WC, Hankinson SE: Plasma 25-hydroxyvitamin D and risk of breast cancer in the Nurses' Health Study II. Breast Cancer Res 2011, 13(3):R50.

12. Engel P, Fagherazzi G, Boutten A, Dupre T, Mesrine S, Boutron-Ruault MC, Clavel-Chapelon F: Serum 25(OH) vitamin D and risk of breast cancer: a nested case-control study from the French E3N cohort. Cancer Epidemiol Biomarkers Prev 2010, 19(9):2341-2350

13. Freedman DM, Chang S-C, Falk RT, Purdue MP, Huang W-Y, McCarty CA, Hollis BW, Graubard BI, Berg CD, Ziegler RG: Serum levels of Vitamin D metabolites and breast cancer risk in the prostate, lung, colorectal, and ovarian cancer screening trial. Cancer Epidemiol Biomarkers Prev 2008, 17(4):889-894.

14. McCullough ML, Stevens VL, Patel R, Jacobs EJ, Bain EB, Horst RL, Gapstur SM, Thun MJ, Calle EE: Serum 25-hydroxyvitamin D concentrations and postmenopausal breast cancer risk: a nested case control study in the Cancer Prevention Study-II Nutrition Cohort. Breast Cancer Res 2009, 11(4):R64.

15. Rejnmark $L$, Tietze A, Vestergaard $P$, Buhl L, Lehbrink $M$, Heickendorff $L$, Mosekilde L: Reduced prediagnostic 25-hydroxyvitamin D levels in women with breast cancer: a nested case-control study. Cancer Epidemiol Biomarkers Prev 2009, 18(10):2655-2660.

16. Scarmo S, Afanasyeva $Y$, Lenner $P$, Koenig K, Horst R, Clendenen T, Arslan A, Chen $Y$, Hallmans $G$, Lundin $E$, et al: Circulating levels of 25 -hydroxyvitamin D and risk of breast cancer: a nested case-control study. Breast Cancer Res 2013, 15(1):R15

17. Chlebowski RT, Johnson KC, Kooperberg C, Pettinger M, Wactawski-Wende J, Rohan T, Rossouw J, Lane D, O'Sullivan MJ, Yasmeen S, et al: Calcium plus Vitamin D supplementation and the risk of breast cancer. J Natl Cancer Inst 2008, 100(22):1581-1591.

18. Neuhouser ML, Manson JE, Millen A, Pettinger M, Margolis K, Jacobs ET, Shikany JM, Vitolins M, Adams-Campbell L, Liu S, et al: The influence of health and lifestyle characteristics on the relation of serum 25-hydroxyvitamin D with risk of colorectal and breast cancer in postmenopausal women. Am J Epidemiol 2012, 175(7):673-684

19. Ford L, Graham V, Wall A, Berg J: Vitamin D concentrations in an UK inner-city multicultural outpatient population. Ann Clin Biochem 2006, 43(Pt 6):468-473.

20. Holick M: Environmental factors that influence the cutaneous production of vitamin D. Am J Clin Nutr 1995, 61(3):638S-645S

21. Nessvi S, Johansson L, Jopson J, Stewart A, Reeder A, McKenzie R, Scragg RK: Association of 25-hydroxyvitamin D3)levels in adult New Zealanders with ethnicity, skin color and self-reported skin sensitivity to sun exposure. Photochem Photobiol 2011, 87(5):1173-1178.

22. Ashwell M, Stone EM, Stolte H, Cashman KD, Macdonald H, Lanham-New S, Hiom S, Webb A, Fraser D: UK Food Standards Agency Workshop Report: an investigation of the relative contributions of diet and sunlight to vitamin D status. Br J Nutr 2010, 104(4):603-611.

23. Looker AC, Pfeiffer CM, Lacher DA, Schleicher RL, Picciano MF, Yetley EA: Serum 25-hydroxyvitamin D status of the US population: 1988-1994 compared with 2000-2004. Am J Clin Nutr 2008, 88(6):1519-1527.

24. IOM (Institue of Medicine): Dietary reference intakes for calcium and vitamin D. Washington, D.C: The National Academy Press; 2011.

25. Rosen CJ, Abrams SA, Aloia JF, Brannon PM, Clinton SK, Durazo-Arvizu RA, Gallagher JC, Gallo RL, Jones G, Kovacs CS, et al: IOM Committee Members Respond to Endocrine Society Vitamin D Guideline. J Clin Endocrinol Metab 2012, 97(4):1146-1152

26. Holick MF, Binkley NC, Bischoff-Ferrari HA, Gordon CM, Hanley DA, Heaney RP, Murad MH, Weaver CM: Evaluation, treatment, and prevention of Vitamin D deficiency: an Endocrine Society Clinical Practice Guideline. J Clin Endocrinol Metab 2011, 96(7):1911-1930.

27. Kolonel LN, Henderson BE, Hankin JH, Nomura AM, Wilkens LR, Pike MC, Stram DO, Monroe KR, Earle ME, Nagamine FS: A multiethnic cohort in Hawaii and Los Angeles: baseline characteristics. Am J Epidemio/ 2000, 151(4):346-357.

28. Pastor R, Guallar E: Use of two-segmented logistic regression to estimate change-points in epidemiologic studies. Am J Epidemiol 1998, 148(7):631-642.

29. Manson JE, Mayne ST, Clinton SK: Vitamin D and prevention of cancer-ready for prime time? N Engl J Med 2011, 364(15):1385-1387.
30. Nicholas J: Vitamin D and cancer: uncertainty persists; research continues. J Natl Cancer Inst 2011, 103(11):851-852.

31. Zerwekh JE: Blood biomarkers of vitamin D status. Am J Clin Nutr 2008, 87(4):1087S-1091S

32. Engel P, Fagherazzi G, Mesrine S, Boutron-Ruault MC, Clavel-Chapelon F Joint effects of dietary vitamin $D$ and sun exposure on breast cancer risk: results from the French E3N cohort. Cancer Epidemiol Biomarkers Prev 2011, 20(1):187-198.

33. John EM, Schwartz GG, Dreon DM, Koo J: Vitamin D and breast cancer risk: The NHANES I epidemiologic follow-up study, 1971-1975 to 1992. Cancer Epidemiol Biomarkers Prev 1999, 8(5):399-406.

34. Bolland MJ, Grey A, Gamble GD, Reid IR: Calcium and vitamin D supplements and health outcomes: a reanalysis of the Women's Health Initiative (WHI) limited-access data set. Am J Clin Nutr 2011, 94(4):1144-1149.

35. Chai W, Maskarinec G, Cooney RV: Serum 25-hydroxyvitamin D levels and mammographic density among premenopausal women in a multiethnic population. Eur J Clin Nutr 2010, 64(6):652-654.

36. Kuroda T, Shiraki M, Tanaka S, Ohta H: Contributions of 25-hydroxyvitamin $D$, co-morbidities and bone mass to mortality in Japanese postmenopausal women. Bone 2009, 44(1):168-172.

37. Millen AE, Wactawski-Wende J, Pettinger M, Melamed ML, Tylavsky FA, Liu S, Robbins J, LaCroix AZ, LeBoff MS, Jackson RD: Predictors of serum 25-hydroxyvitamin D concentrations among postmenopausal women: the Women's Health Initiative Calcium plus Vitamin D clinical trial. Am J Clin Nutr 2010, 91(5):1324-1335.

38. Ohta H, Kuroda T, Onoe Y, Orito S, Ohara M, Kume M, Harada A, Tsugawa N, Okano T, Sasaki S: The impact of lifestyle factors on serum 25-hydroxyvitamin D levels: a cross-sectional study in Japanese women aged 19-25 years. J Bone Miner Metab 2009, 27(6):682-688.

39. Anderson LN, Cotterchio M, Cole DE, Knight JA: Vitamin D-related genetic variants, interactions with vitamin D exposure, and breast cancer risk among Caucasian women in Ontario. Cancer Epidemiol Biomarkers Prev 2011, 20(8):1708-1717

40. Ingles SA, Garcia DG, Wang W, Nieters A, Henderson BE, Kolonel LN, Haile RW, Coetzee GA: Vitamin D receptor genotype and breast cancer in Latinas (United States). Cancer Causes Control 2000, 11(1):25-30.

41. McKay JD, McCullough ML, Ziegler RG, Kraft P, Saltzman BS, Riboli E, Barricarte A, Berg CD, Bergland G, Bingham S, et al: Vitamin D receptor polymorphisms and breast cancer risk: results from the National Cancer Institute Breast and Prostate Cancer Cohort Consortium. Cancer Epidemiol Biomarkers Prev 2009, 18(1):297-305

42. Rollison DE, Cole AL, Tung KH, Slattery ML, Baumgartner KB, Byers T, Wolff RK, Giuliano AR: Vitamin D intake, vitamin D receptor polymorphisms, and breast cancer risk among women living in the southwestern U.S. Breast Cancer Res Treat 2011, 132(2):683-691.

43. Trabert B, Malone KE, Daling JR, Doody DR, Bernstein L, Ursin G, Marchbanks PA, Strom BL, Humphrey MC, Ostrander EA: Vitamin D receptor polymorphisms and breast cancer risk in a large population-based case-control study of Caucasian and African-American women. Breast Cancer Res 2007, 9(6):R84.

44. Khan QJ, Kimler BF, Fabian CJ: The relationship between vitamin D and breast cancer incidence and natural history. Curr Oncol Rep 2010, 12(2):136-142.

45. John EM, Schwartz GG, Koo J, Wang W, Ingles SA: Sun exposure, vitamin D receptor gene polymorphisms, and breast cancer risk in a multiethnic population. Am J Epidemiol 2007, 166(12):1409-1419.

46. Li B, Byrjalsen I, Glendenning P, Henriksen DB, Hoeck HC, Taranto M, Vasikaran S, Fraser WD, Christiansen C, Qvist P: Selective monitoring of vitamin D2 and D3 supplementation with a highly specific 25hydroxyvitamin D3 immunoassay with negligible cross-reactivity to 25-hydroxyvitamin D2. Clin Chim Acta 2009, 404(2):144-148.

47. Heaney RP, Recker RR, Grote J, Horst RL, Armas LA: Vitamin D(3) is more potent than vitamin D(2) in humans. J Clin Endocrinol Metab 2011, 96(3):E447-452.

48. Houghton LA, Vieth R: The case against ergocalciferol (vitamin D2) as a vitamin supplement. Am J Clin Nutr 2006, 84(4):694-697.

49. Chlebowski RT: Vitamin D and breast cancer: interpreting current evidence. Breast Cancer Res 2011, 13(4):217.

doi:10.1186/1471-2407-14-29

Cite this article as: Kim et al.: Plasma 25-hydroxyvitamin D3 is associated with decreased risk of postmenopausal breast cancer in whites: a nested case-control study in the multiethnic cohort study. BMC Cancer 2014 14:29. 